\title{
Germination and Embryo Anatomy of Osmotically Primed Parsley Schizocarps
}

\author{
Michael W. Olszewski ${ }^{1}$, Wallace G. Pill ${ }^{2}$, and Thompson D. Pizzolato ${ }^{2}$ \\ University of Delaware, Department of Plant and Soil Sciences, Newark, DE 19717-1303
}

ADDITIONAL INDEX WORDS. Apiaceae, Petroselinum crispum, priming, seed treatment, Umbelliferae

\begin{abstract}
Moss Curled'parsley [Petroselinum crispum (Mill.) Nyman ex.A.W.Hill] schizocarps were osmotically primed in polyethylene glycol at -1.0 MPa for 7 days at $20^{\circ} \mathrm{C}$. The smaller of the two mericarps within a parsley schizocarp had lower germination percentage, but similar rate and synchrony of germination. Osmotic priming increased germination percentage, rate, and synchrony, irrespective of mericarp half. This promotive effect of priming on germination was associated with embryonic advancement as indicated by a doubling of radicle and cotyledon volumes, without changes in lengths of these organs. Periclinal divisions of the lateral expansion meristem, distinct in primed radicles but indistinct in nonprimed radicles, led to radial alignment of the cortical cells and a doubling of cortical volume and thereby increased radicle volume. Each embryonic cotyledon of primed mericarps had three distinct procambial bundles that differentiated along most of the cotyledon length, while nonprimed cotyledons had from zero to three that differentiated only a short way into the cotyledon. Priming increased coyledonary procambium length by 5-fold and volume by 11-fold. Increased embryonic growth due to priming was associated with greater endosperm depletion adjacent to the embryo. The schizocarps frequently separated or partially separated into component mericarps during priming, indicating a weakening of pericarp tissue along the commissural suture and possibly elsewhere.
\end{abstract}

The fruit of the Apiaceae (Umbelliferae) is a schizocarp consisting of two single-seeded mericarps that split at maturity along the commissural suture (Fig. 1). Since schizocarps shatter when mature and separate the two mericarp halves, the presence of entire schizocarps in a seed lot indicates the presence of immature embryos. The embryo, surrounded by a large amount of endosperm, is located at the distal end of the mericarp (Martin, 1946). Seedlots contain primarily mericarps, but can contain high percentages of schizocarps, often comprised of a larger mericarp and a smaller one. There is no known research relating mericarp size within a schizocarp to germination rate and percentage. Slow and erratic germination in several umbelliferous species has been attributed to inhibitory substances in the covering structures of the seed (Chaturvedi and Muralia, 1975) and to embryo immaturity (Gray and Steckel, 1983). Slowness of parsley germination is exemplified by the allowance of 10 and $28 \mathrm{~d}$ before the first and last germination counts, respectively (Internal Seed Testing Association, 1985).

Seed priming is their exposure to sufficiently low water potentials, osmotically or matrically induced, to permit hydration but prevent radicle protrusion (see review by Pill, 1995). Priming of parsley mericarps [-1.2 MPa polyethylene glycol (PEG) for 3 weeks at $15{ }^{\circ} \mathrm{C}$ ] gave greater, earlier and more synchronous emergence (Ely and Heydecker, 1981), with washing the mericarps for $24 \mathrm{~h}$ in continuously running water before priming giving no additional benefit. This same priming treatment (Pill, 1986) gave earlier emergence and greater seedling shoot weights, but had no effect on emergence percentage of parsley. Daily change of the PEG solution provided no additional benefit. Priming parsley mericarps in PEG $\left(-0.5 \mathrm{MPa}\right.$ for $3 \mathrm{~d}$ at $25^{\circ} \mathrm{C}$, then -0.8 MPa for $1.5 \mathrm{~d})$ hastened parsley germination but had no effect on emergence synchrony or percentage (Akers et al., 1987). Matric priming in fine exfoliated vermiculite $(-0.5 \mathrm{MPa}$ for $7 \mathrm{~d}$ at 30 ${ }^{\circ} \mathrm{C}$ ) was a satisfactory alternative to osmotic priming (Pill and

Received for publication 5 May 2004. Accepted for publication 11 Aug. 2004. 'Graduate Student.

${ }^{2}$ Professor.
Kilian, 2000). Priming of parsley mericarps can increase yield at early harvest and decrease seeding rate, resulting in $5 \%$ predicted production savings (Rabin et al., 1988). The present study focuses on the germination differences of the schizocarp halves. Priming increased embryo length (Dawidowicz-Grzegorzewska and Maguire, 1993) and embryo cell number and volume (Gray et al., 1990) in carrot (Daucus carota L.). In celery (Apium graveolens L.), osmotic priming increased embryo cell division and size and total embryo length (van der Toorn, 1989). There are no known reports of embryonic anatomy of primed parsley. We hypothesize that priming affects the primary tissue systems of the embryo including the procambium and radicle cortex, in addition to affecting embryo length and volume as noted above in carrot and celery. The objectives of this study were to determine differences in anatomy/morphology and germination between large and small halves of the schizocarp, and the effects of osmotic priming on parsley embryo anatomy.

\section{Materials and Methods}

OSMOTIC PRIMING AND GERMINATION. A seed lot (single mericarps mixed with schizocarps) of 'Moss Curled' parsley was obtained commercially with a labeled germination of $80 \%$. The seed lots contained $12.5 \%$ (weight) of schizocarps. Schizocarps $(0.9 \mathrm{~g})$ were primed in $125 \times 80 \times 20$-mm transparent polystyrene boxes containing two layers of germination blotters (Germination Blotter No. 385; Seedburo, Chicago) moistened with $15 \mathrm{~mL}$ of PEG 6000 solutions, equivalent to $-1.0 \mathrm{MPa}$ osmotic potential (Michel and Kaufmann, 1973). Schizocarps were osmotically primed at $20^{\circ} \mathrm{C}$ for $7 \mathrm{~d}$ in darkness. To reduce changes in water potential during osmotic priming, PEG solutions were changed every $24 \mathrm{~h}$. After osmotic priming, schizocarps were triple-rinsed in deionized water to remove PEG and then dried for $7 \mathrm{~d}$ at 21 ${ }^{\circ} \mathrm{C}$ and $44 \%$ relative humidity.

Nonprimed and primed schizocarps were sown into $125 \times 80$ $\times 20$-mm transparent polystyrene boxes containing two germination blotters and $15 \mathrm{~mL}$ deionized water. The germination test occurred at $20^{\circ} \mathrm{C}$ using 15 schizocarps for each of 12 replications. 


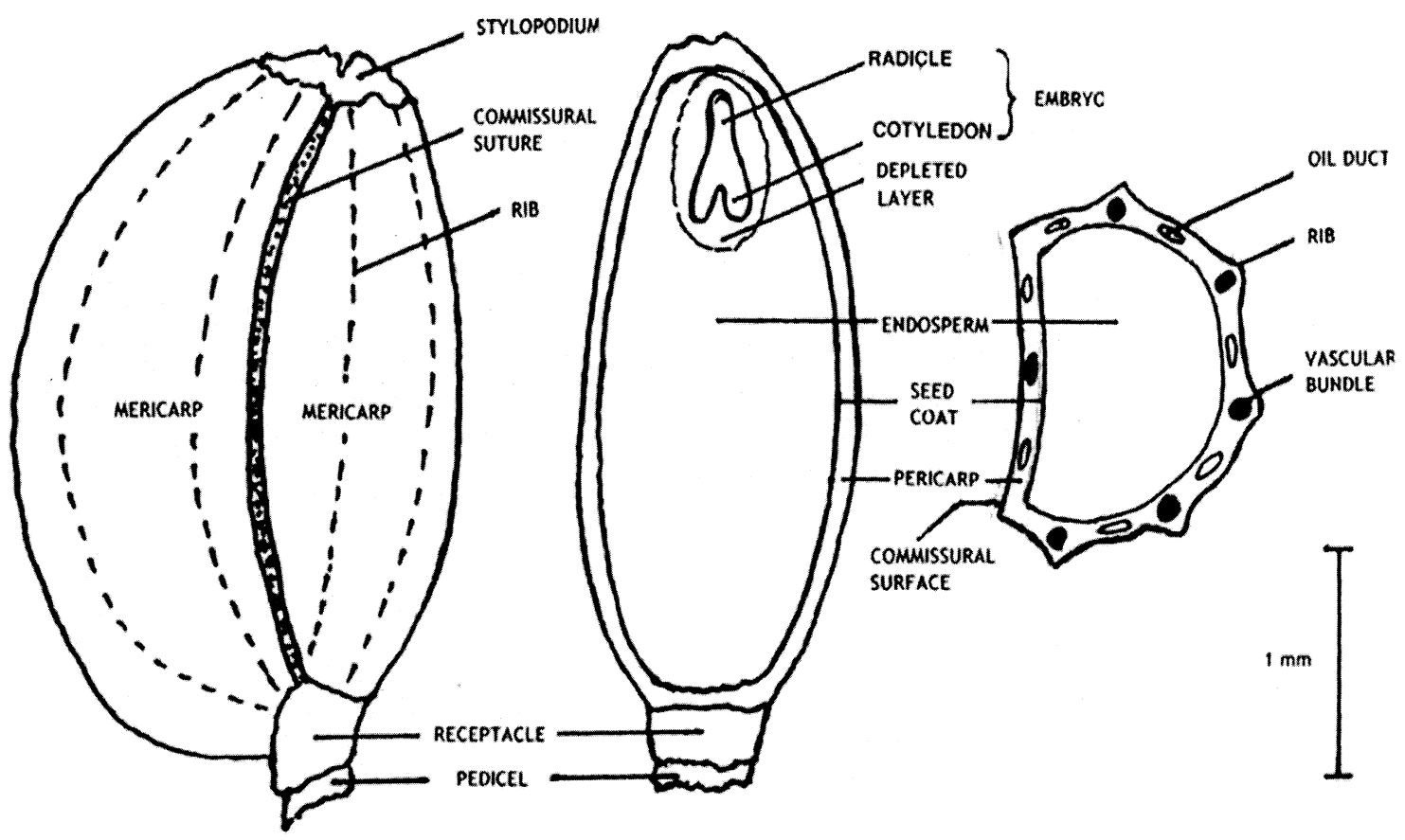

THE PARSLEY SCHIZOCARP

MERICARP LONGITUDINAL SECTION MERICARP TRANSVERSE'SECTION

Fig. 1. General morphology of the parsley schizocarp. (left) Two single-seeded mericarps. (center) Longitudinal section of a mericarp showing the embryo at the distal end. (right) Transverse section through the mericarp midsection.

Schizocarps were laid flat on the blotters in three rows of five schizocarps each. Commissural sutures were aligned parallel to the row axis, with the large mericarp always on the same side of all rows. Germination (visible radicle protrusion) of mericarps was counted every $12 \mathrm{~h}$ until $3 \mathrm{~d}$ in succession without germination, germinated mericarps being removed from the boxes when they were counted. Final germination percentage (FGP) and its transformation $\left(\arcsin \sqrt{ } \%\right.$ ), days to $50 \%$ FGP $\left(\mathrm{G}_{50}\right)$ and days between $10 \%$ and $90 \% \mathrm{FGP}\left(\mathrm{G}_{10-90}\right)$ were calculated and subjected to analysis of variance.

ANATOMY AND MORPhOlogy. A histological protocol similar to that of Jensen (1962) was used. Four nonprimed or primed schizocarps were soaked in $10 \%$ buffered formalin phosphate for 2.5 weeks. To aid chemical infiltration, schizocarps were cut transversely and centrally with a razor blade. Dehydration was under vacuum and used a $70 \%$ to $100 \%$ ethanol series followed by xylene infiltration, also under vacuum. Infiltration with paraffin was under vacuum for 8 to $12 \mathrm{~d}$. Transverse sections were cut with an M1R rotary microtome (Shandon, Pittsburgh) at a setting of $6 \mu \mathrm{m}$; however, actual section thickness was estimated to be $7.1 \mu \mathrm{m}$ using the "fold-method" (Bozzola and Russell, 1992). Sections were deparaffinized, stained with $0.5 \%$ safranin, then $0.5 \%$ fast green, and permanently mounted. Length of each embryonic organ or tissue was determined by multiplying section thickness (t) by the number of transverse sections included in a given organ or tissue. Organ or tissue area $\left(a_{e}\right)$ was estimated on every fifth serial section by tracing their outlines projected through a drawing tube attached to a Wild M20 microscope (Martin Microscope Co, Easley, S.C.), followed by referencing to a $0.25-\mathrm{mm}^{2}$ standard. Tracings were cut out and their areas (Pizzolato, 1983) determined with a LI-3000A area meter (LICOR, Lincoln, Nebr.). Organ or tissue volume $\left(\mathrm{V}_{\mathrm{o}}\right)$ was calculated using the equation: $\mathrm{V}_{\mathrm{o}}=\left(\Sigma \mathrm{a}_{\mathrm{e}}\right) \mathrm{t}$.
In order to view freshly harvested schizocarps, 8-week-old plants grown singly in 20-cm-diameter pots containing peat-lite (ProMix BX; Premier Horticulture, Red Hill, Pa.) were vernalized $\left(6^{\circ} \mathrm{C}\right.$ for 5 weeks) to produce primary and secondary umbels with mature mericarps by 36 weeks after vernalization. Schizocarps that had not shattered from secondary umbels were mounted on sticky carbon tape and viewed with a Hitachi S-4700 field emission scanning electron microscope (Hitachi, Schaumburg, Ill.) at $0.7 \mathrm{kV}$.

\section{Results and Discussion}

Most schizocarps contained a small and a large mericarp (Figs. $1,2 \mathrm{~A}$, and $3 \mathrm{~B}$ ), but occasionally the mericarps were approximately equal in diameter (Fig. 3A).

OSMOTIC PRIMING AND GERMINATION. The FGP of small mericarps (67\%) was lower than that of large ones (75\%), but mericarp size did not affect $\mathrm{G}_{50}$ or $\mathrm{G}_{10-90}$ (Table 1). Irrespective of mericarp size, priming increased FGP and decreased $\mathrm{G}_{50}$ and $\mathrm{G}_{10-90}$. The lower $\mathrm{G}_{50}$ of primed mericarps $(6.5 \mathrm{~d})$ than of nonprimed mericarps (10.0 d), agreed with the results of Ely and Heydecker (1981) and Pill (1986). The more synchronous germination of primed mericarps $\left(\mathrm{G}_{10-90}\right.$ of $\left.5.3 \mathrm{~d}\right)$ compared to nonprimed mericarps $\left(\mathrm{G}_{10-90}\right.$ of $7.5 \mathrm{~d}$ ) was reported in parsley (Pill and Kilian, 2000), although Akers et al. (1987) noted that priming had no effect on parsley germination synchrony.

In the current study, more than one-fifth of mericarps did not germinate. Borthwick (1931) attributed reduced carrot germination percentage to defective embryos. We observed that small mericarps frequently contained no embryos; however, it was unknown whether their mericarps were truly embryoless or their small embryos were lost during histological preparation. Anatomically, embryos of small mericarps were less developed (i.e., shorter and 

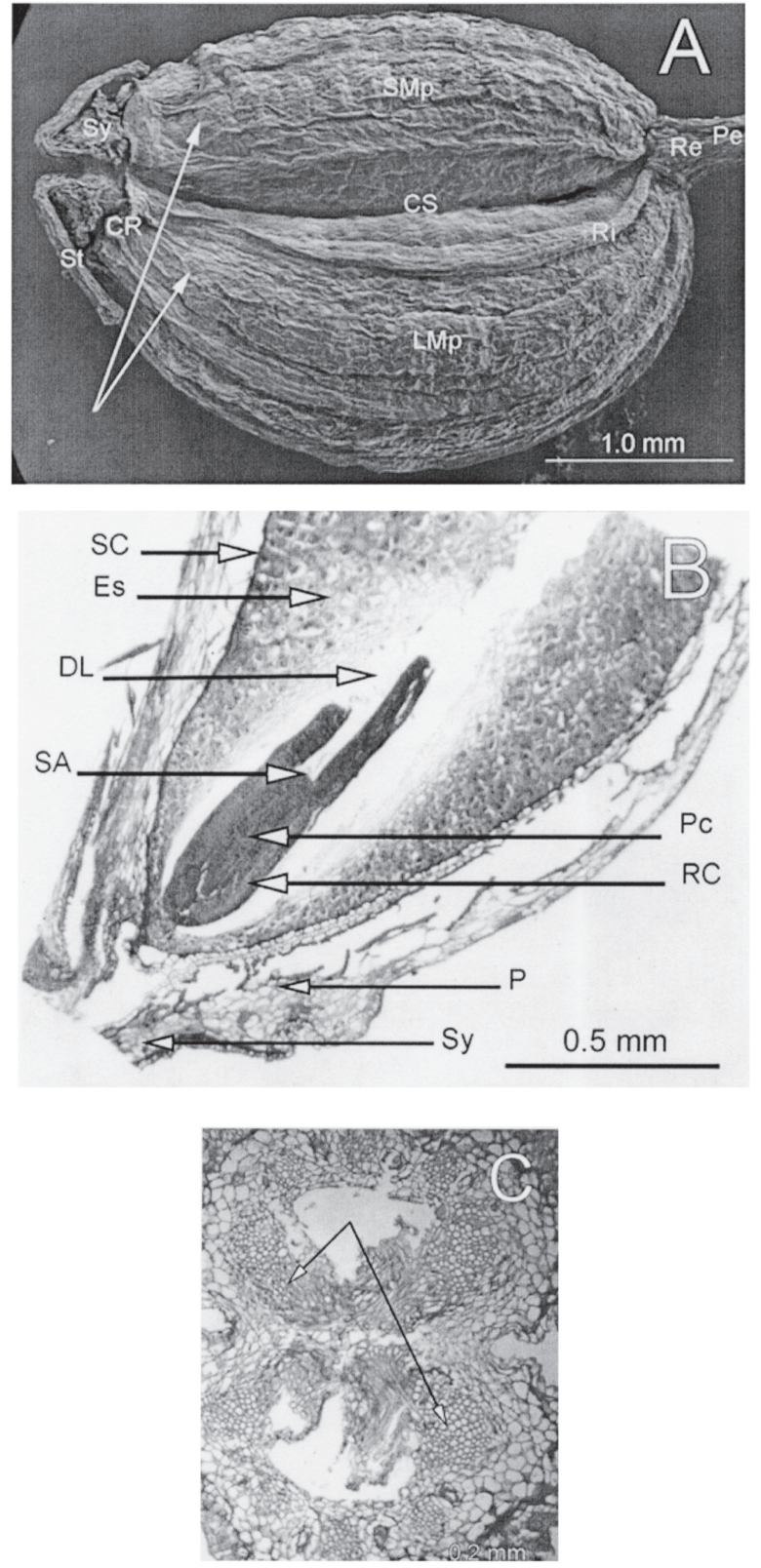

Fig. 2. (A) Scanning electron micrograph of a nonprimed parsley schizocarp. $\mathrm{CR}=$ calyx rim; $\mathrm{CS}=$ commissural suture LMp = large mericarp; $\mathrm{Pe}=$ Pedicel $; \mathrm{Ri}=$ rib $; \mathrm{Re}=$ receptacle $; \mathrm{SMp}=$ small mericarp $; \mathrm{St}=$ stylar remnant; Sy $=$ stylopodium. Arrows indicate the general location of the embryos. (B) Longitudinal section of distal end of nonprimed parsley mericarp. SC $=$ seed coat; $\mathrm{Es}=$ endosperm; DL = depleted layer: $\mathrm{SA}=$ shoot apex (showing lack of epicotyl); $\mathrm{P}=$ pericarp; $\mathrm{Pc}=$ procambium of radicle (showing lack of hypocotyl); $\mathrm{RC}=$ root cortex; Sy = stylopodium. (C) Ring (arrows) of sclerified tissue in the pericarp at the convergence of the ribs at the distal end of the schizocarp in the stylopodium region.

of lower volume) than those of large mericarps (data not shown). A high degree of embryoless mericarps occurs in agricultural Apiaceae including carrot, celery, dill (Anethum graveolens L.), parsley, and parsnip (Pastinaca sativa L.), affecting $0 \%$ to $16 \%$, $2 \%$ to $8 \%, 1 \%$ to $24 \%, 13 \%$ to $20 \%$, and $1 \%$ to $8 \%$, respectively (Flemion and Henrickson, 1949; Flemion and Uhlmann, 1946). In the current study, some small mericarps were truly embryoless because they contained a solid core of endosperm with no space for an embryo. All large mericarps had embryos.
Anatomy And MoRPhOlogy. Dicotyledonous embryos usually consist of two cotyledons attached to a radicle-hypocotyl axis, with procambium forming a provascular continuum from radicle to cotyledons (Esau, 1977). However, the parsley embryo has a minimal epicotyl and hypocotyl. Since there were never more, and frequently fewer, than three serial cross sections showing pith in the center of the procambium located above the radicle's solid procambium, the maximal hypocotyl length was only $\approx 21 \mu \mathrm{m}$. Thus, the parsley embryo consists primarily of cotyledons and a radicle axis (Fig. 2B). Around the centrally located procambium of the radicle, at the innermost portion of the cortex, is the lateral expansion meristem (LEM), which is responsible for increased cortical width (Mahlberg, 1960). For both nonprimed and primed embryos, the embryonic cortical cells were less densely stained, less protoplasmic, and more vacuolated than the procambial cells. The LEM cells of primed embryos were usually more defined (Fig. 3D) than the less distinct ones of nonprimed embryos (Fig. 3C), reflecting developmental advancement (with increased cell division) of this tissue with priming. Compared to adjacent procambial cells, LEM cells enlarge at an earlier developmental stage and have thicker and denser cell walls (Mahlberg, 1960). The LEM cells of primed embryos underwent mitosis within 24 $\mathrm{h}$ of imbibition whereas those of nonprimed embryos did not (Olszewski, 2004), an advancement which could lead to faster germination of primed mericarps (Table 1). Greater LEM periclinal divisions with priming led to a more pronounced radial alignment of the cortical cells (Fig. 3D). Priming had no effect on radicle length, but doubled the radicle volume (Table 2). Since neither radicle procambial volume nor length was affected by priming, increased radicle volume with priming could be attributed to increased cortical volume (Table 2). Also, priming increased vacuolization of the ground meristem, and increased intercellular space formation within the cortex (Olszewski, 2004), characteristics associated with increased tissue maturation. Esau (1977) stated that vacuoles enlarge and coalesce during cell growth and differentiation, and that intercellular spaces are characteristic of mature tissue.

Priming did not increase embryonic cotyledon length, but doubled cotyledon volume (Table 2), a response that reflected increased procambial activity. Priming increased cotyledon procambium length 5-fold and its volume almost 11-fold (Table 2 ). Priming typically resulted in a well-developed procambium in three distinct procambial bundles (Fig. 3F) that differentiated along most of the length $(\approx 80 \%)$ of the cotyledons (Table 2$)$. The median procambial bundle was distinct in cotyledons of nonprimed mericarps, with the two smaller flanking (lateral) bundles typically being indistinct (Fig. 3E). No bundles of the nonprimed embryos extend the entire length of the cotyledons. These observations are interesting since Bailey (1956) states that the embryonic cotyledons of the Apiaceae have three distinct procambial bundles. Thus, the primed embryos more resemble those described by Bailey (1956) than the nonprimed embryos. The greater procambial differentiation with priming probably led to faster germination since this may be the first seed tissue to become metabolically active upon imbibition (Werker, 1997). Moreover, embryonic vascular tissues are capable of transporting auxin (Fry and Wangermann, 1976). While we found that priming increased the volumes of both the cotyledons and radicles (Table 2), Dawidowicz-Grzegorzewska and Maguire (1993) noted that priming mostly affected the radicle-hypocotyl axis in carrot. Gray et al. (1990) noted increased carrot embryo volume with priming. 


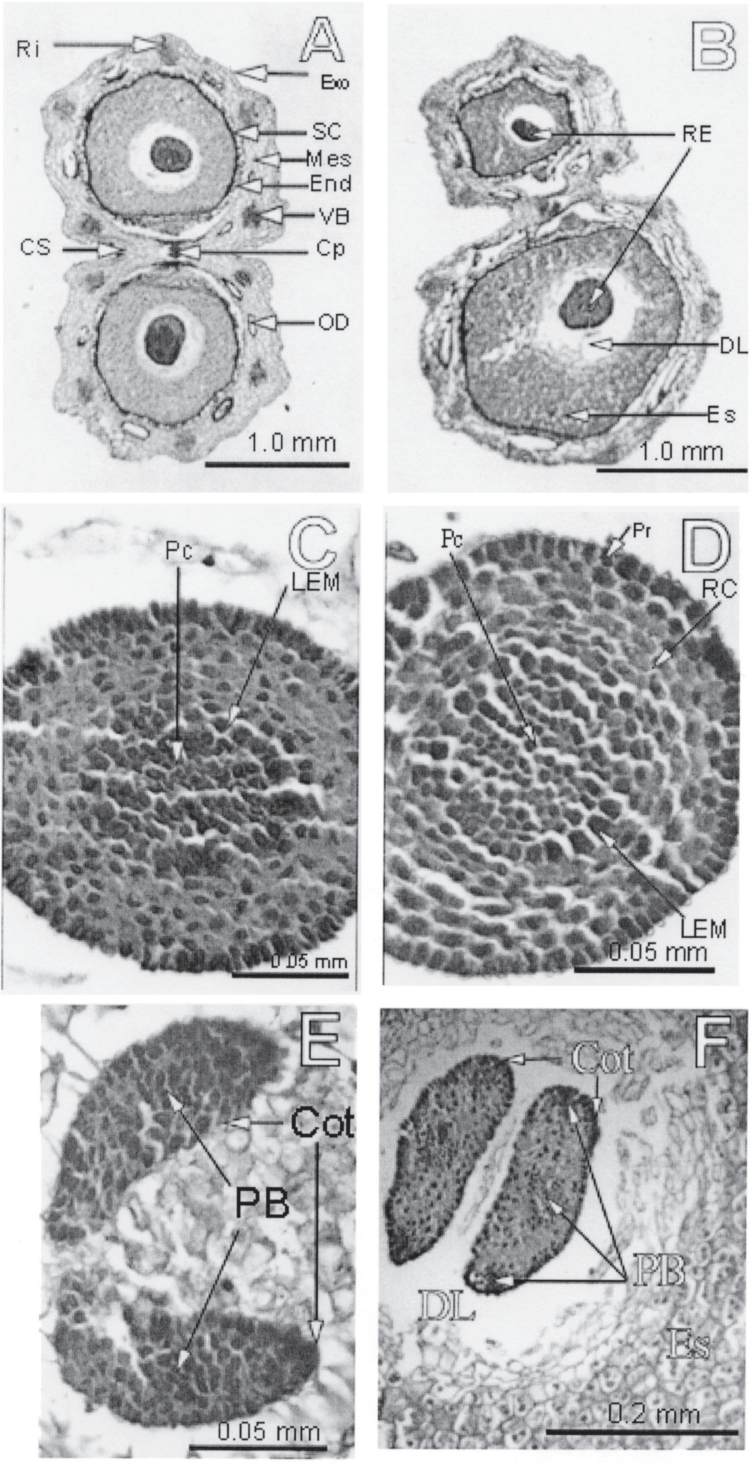

Fig. 3. (A) Nonprimed schizocarp with mericarps of similar size; (B) Transverse section of primed parsley schizocarp with dimorphic mericarps; (C) Nonprimed radicle axis with little distinction between procambium and embryonic cortex; (D) Primed radicle axis with radial alignment of embryonic cortical cells and distinct LEM; (E) Nonprimed cotyledons with centrally distinct procambial bundle but indistinct lateral bundles; (F) Primed cotyledons with distinct median and lateral procambial bundles. $\mathrm{Cp}=$ carpophore; $\mathrm{CS}=$ commissural suture; Cot = cotyledons $;$ DL = depleted layer; End = endocarp; Es = endosperm; Exo = exocarp; LEM = lateral expansion meristem; Mes = mesocarp; OD = oil duct; $\mathrm{PB}=$ procambial bundle $; \mathrm{Pc}=$ procambium; $\mathrm{Pr}=$ protoderm $; \mathrm{RC}=$ radicle cortex; $\mathrm{Ri}=$ rib; $\mathrm{RE}=$ radicle of the embryo; $\mathrm{SC}=$ seed coat; $\mathrm{VB}=$ vascular bundle.

Celery endosperm cells are mostly thick-walled, but smaller at the radicle end than at other regions surrounding the embryo (Jacobsen and Pressman, 1979). We observed that parsley endosperm morphology (Fig. 2B) was similar to that of celery. Thinning of the endosperm, particularly at the radicle end of the embryo, may reduce the resistance to radicle protrusion and thereby hasten germination in primed parsley, as Oluoch and Welbaum (1996) reported in muskmelon (Cucumis melo L.). We hypothesize, however, that the fewer layers of endosperm cells with thinner walls at the radicle end of the embryo than at the proximal end of the embryo provide little resistance to radicle protrusion. Werker
Table 1. Effect of priming on final germination percentage (FGP, and its $\arcsin \sqrt{ } \%$ transformation in degrees), days to $50 \%$ of FGP $\left(\mathrm{G}_{50}\right)$, and days between $10 \%$ and $90 \%$ of FGP $\left(\mathrm{G}_{10-90}\right)$ of the small mericarp and the large mericarp within a schizocarp of 'Moss Curled' parsley.

\begin{tabular}{lcccc}
\hline $\begin{array}{l}\text { Schizocarp } \\
\text { treatment }\end{array}$ & $\begin{array}{c}\text { Mericarp } \\
\text { size within a } \\
\text { schizocarp }\end{array}$ & $\begin{array}{c}\text { FGP } \\
\%\end{array}$ & $\begin{array}{c}\mathrm{G}_{50} \\
(\text { degrees })\end{array}$ & $\begin{array}{c}\mathrm{G}_{10-90} \\
(\mathrm{~d})\end{array}$ \\
\hline Nonprimed & Small & $62(52) \mathrm{c}$ & $9.6 \mathrm{a}$ & $7.2 \mathrm{a}$ \\
& Large & $71(57) \mathrm{b}$ & $10.4 \mathrm{a}$ & $7.7 \mathrm{a}$ \\
Primed & Small & $72(58) \mathrm{b}$ & $6.4 \mathrm{~b}$ & $5.1 \mathrm{~b}$ \\
& Large & $78(63) \mathrm{a}$ & $6.7 \mathrm{~b}$ & $5.4 \mathrm{~b}$ \\
LSD $_{0.05}{ }^{\mathrm{z}}$ & & $(4)$ & 1.5 & 2.4 \\
Significance & & & & \\
Seed treatment (ST) & & $(* *)$ & $* * *$ & $* *$ \\
Mericarp Size (MS) & & $(*)$ & $\mathrm{NS}$ & $\mathrm{NS}$ \\
ST $\times$ MS & & $(\mathrm{NS})$ & $\mathrm{NS}$ & $\mathrm{NS}$ \\
\hline
\end{tabular}

${ }^{2}$ Least significant difference, $P \leq 0.05$.

NS, ***,**, *Nonsignificant or significant at $P \leq 0.001,0.01$, or 0.05 , respectively.

Table 2. Embryo tissue lengths and volumes for nonprimed and primed larger mericarps within a schizocarp of 'Moss Curled' parsley.

\begin{tabular}{|c|c|c|}
\hline \multirow[b]{2}{*}{ Embryo tissue } & \multicolumn{2}{|c|}{ Schizocarp treatment ${ }^{z}$} \\
\hline & $\begin{array}{c}\text { Nonprimed } \\
(\text { mean } \pm \mathrm{SE}, \mathrm{n}=4)\end{array}$ & $\begin{array}{c}\text { Primed } \\
(\text { mean } \pm \text { SE, } n=4)\end{array}$ \\
\hline & \multicolumn{2}{|c|}{ Length of embryo components $(\mathrm{mm})$} \\
\hline Embryo & $0.53 \pm 0.13$ & $0.60 \pm 0.07$ \\
\hline Cotyledons & $0.24 \pm 0.07$ & $0.28 \pm 0.05$ \\
\hline Radicle & $0.29 \pm 0.06$ & $0.32 \pm 0.06$ \\
\hline Procambium & $0.30 \pm 0.07$ & $0.49 \pm 0.13$ \\
\hline Cotyledons & $0.05 \pm 0.02$ & $0.23 \pm 0.09$ \\
\hline \multirow[t]{2}{*}{ Radicle } & $0.25 \pm 0.05$ & $0.26 \pm 0.05$ \\
\hline & \multicolumn{2}{|c|}{ Volume $\left(\mathrm{mm}^{3} 10^{-3}\right) \mathrm{y}$} \\
\hline Embryo & $8.2 \pm 2.6$ & $16.0 \pm 4.0$ \\
\hline Cotyledons & $3.7 \pm 1.4$ & $7.6 \pm 2.3$ \\
\hline Radicle & $4.5 \pm 1.3$ & $8.1 \pm 1.9$ \\
\hline Procambium & $1.1 \pm 0.3$ & $2.1 \pm 0.7$ \\
\hline Cotyledons & $0.09 \pm 0.05$ & $1.01 \pm 0.48$ \\
\hline Radicle & $1.02 \pm 0.26$ & $1.14 \pm 0.24$ \\
\hline Radicle cortex ${ }^{z}$ & $3.5 \pm 1.0$ & $7.1 \pm 1.7$ \\
\hline
\end{tabular}

zThe single cell layer of the protoderm was included.

y Volume $=\left(\sum \mathrm{a}_{\mathrm{e}}\right) \mathrm{t}$, where $\mathrm{a}_{\mathrm{e}}=$ organ or tissue area and $\mathrm{t}=$ section thickness.

(1997) noted that cells with thick, hard walls offer resistance to radicle protrusion. The seed coat and pericarp at the radicular end of the embryo contained sclerified cells that may be weakened by priming, possibly resulting in faster germination.

The fact that schizocarps frequently would separate or partially separate into component mericarps with priming provided evidence that priming weakened pericarp tissues along the commissural suture, and possibly elsewhere. Distal to the radicle end of the embryo in the region of the stylopodium of the mericarp, oil ducts located between the ribs are small, but tracheary elements and associated sclerified tissues from vascular bundles of the five converging ribs form a ring of sclerified tissue (Fig. 2C). It remains unknown whether this sclerified tissue offers a physical barrier to radicle growth, or whether priming weakened these tissues. We noted, however, that priming removed ergastic substances (products of metabolism; Esau, 1977), presumed to 
be essential oils, mucilage, gums, or resin secreted by secretory spaces within oil ducts of umbellifers (Roth, 1977).

The results of this study have shown that the smaller of the two mericarps within a parsley schizocarp had lower germination percentage, but mericarps had similar rate and synchrony of germination. Osmotic priming increased germination percentage, rate and synchrony, irrespective of mericarp half. This promotive effect of priming on germination was associated with embryonic advancement as indicated by increased volumes, but not length, of the radicle and cotyledons. A distinctive LEM in primed mericarp radicles, but not in nonprimed radicles, was associated with increased cortical volume and thereby increased radicle volume. Each cotyledon of primed mericarps had three distinct procambial bundles that differentiated along most $(\approx 80 \%)$ of the cotyledon length, while nonprimed cotyledons typically had fewer, which differentiated only a short way $(\approx 20 \%)$ into the cotyledon. Almost all of the schizocarps partially or completely separated into component mericarps during priming, indicating a weakening of pericarp tissue along the commissural suture.

\section{Literature Cited}

Akers, S.W., G.A. Berkowitz, and J. Rabin. 1987. Germination of parsley seed primed in aerated solutions of polyethylene glycol. HortScience 22:250-252.

Bailey, J.W. 1956. Nodal anatomy in retrospect. J. Arnold Arboretum 37:269-287.

Borthwick, H.A. 1931. Development of the macrogametophyte and embryo of Daucus carota. Bot. Gaz. 92:23-44.

Bozzola, J.J. and L.D. Russell. 1992. Electron microscopy: Principles and techniques for biologists. Jones and Bartlett Publishers, London.

Chaturvedi, S.N. and R.N. Muralia. 1975. Germination inhibitors in some Umbellifer seeds. Ann. Bot. 39:1125-1129.

Dawidowicz-Grzegorzewska, A. and J.D. Maguire. 1993. The effects of SMP on the ultrastructure of carrot seeds. Proc. Fourth Intl. Wkshp. on Seeds 3:1039-1044.

Esau, K. 1977. Plant anatomy. $2^{\text {nd }}$ ed. Wiley, New York.

Ely, P.R. and W. Heydecker. 1981. Fast germination of parsley seeds. Scientia Hort. 15:127-136.

Flemion, F. and E.T. Henrickson. 1949. Further studies on the occurrence of embryoless seeds and immature embryos in the Umbelliferae. Contrib. from the Boyce Thompson Inst. 15:291-297.

Flemion, F. and G. Uhlmann. 1946. Further studies of embryoless seeds in the Umbelliferae. Contrib. from the Boyce Thompson Inst.
14:283-293.

Fry, S.C. and E. Wangermann. 1976. Polar transport of auxin through embryos. New Phytol. 77:313-317.

Gray, D. and J.R.A. Steckel. 1983. Seed quality in carrots: The effects of seed crop plant density, harvest date, and seed grading on seed and seedling variability. J. Hort. Sci. 58: 393-401.

Gray, D., J.R.A. Steckel, and L.J. Hands. 1990. Response of vegetable seeds to controlled hydration. Ann. Bot. 66:227-235.

International Seed Testing Association. 1985. International rules for seed testing. Seed Sci. Technol. 13:299-355.

Jacobsen, J.V. and E. Pressman. 1979. A structural study of germination in celery (Apium graveolens L.) seed with emphasis on endosperm breakdown. Planta 144:241-248.

Jensen, W.A. 1962. Botanical histochemistry. Freeman, San Francisco.

Mahlberg, P.G. 1960. Embryogeny and histogenesis in Nerium oleander L. - I. Organization of primary meristematic tissues. Phytomorphology 10:118-131.

Martin,A.C. 1946. The comparative internal morphology of seeds. Amer. Midland Naturalist 36:513-660.

Michel, B.E. and M.R. Kaufmann. 1973. The osmotic potential of polyethylene glycol 6000. Plant Physiol. 51:914-916.

Olszewski, M.W. 2004. The effects of priming on the anatomy, pathology and germination of parsley mericarps. PhD Diss., Univ. of Delaware, Newark, Del.

Oluoch, M. and G.E. Welbaum. 1996. Viability and vigor of osmotically primed muskmelon seeds after nine years of storage. J. Amer. Soc. Hort. Sci. 121:408-413.

Pill, W.G. 1986. Parsley emergence and seedling growth from raw, osmoconditioned and pregerminated seeds. HortScience 21:1134-1136.

Pill, W.G. 1995. Low water potential and presowing germination treatments to improve seed quality, p. 319-359. In: A.S. Basra (ed.). Seed quality: Basic mechanisms and agricultural implications. Haworth Press, Binghampton, N.Y.

Pill, W.G. and E.A. Kilian. 2000. Germination and emergence of parsley in response to osmotic or matric seed priming and treatment with gibberellin. HortScience 35:907-909.

Pizzolato, T.D. 1983. Vascular system of lodicules of Dactylis glomerata L. Amer. J. Bot. 70:17-29.

Rabin, J., G.A. Berkowitz, and S.W. Akers. 1988. Field performance of osmotically primed parsley seed. HortScience 23:554-555.

Roth, I. 1977. Fruits of angiosperms. Gebruder Bontraeger, Berlin, Germany.

Van der Toorn, P. 1989. Embryo growth in mature celery seeds. PhD Diss., Agricultural Univ., Wageningen, The Netherlands.

Werker, E. 1997. Seed anatomy. Gebruder Borntraeger, Berlin. 